DOI 10.26886/2414-634X.5(24)2018.2

UDC: 657.47

\title{
THE ESSENCE OF INTERNAL (MANAGERIAL) REPORTING AND REQUIREMENTS TO IT
}

\section{N. I. Pylypiv, Doctor of Economics, Professor}

Vasyl Stefanyk Precarpathian National University, Ukraine, Ivano-Frankivsk

\section{D. Piatnychuk, PhD in Economical Sciences}

King Danylo University, Ukraine, Ivano-Frankivsk

\section{M. Motil}

Vasyl Stefanyk Precarpathian National University, Ukraine, Ivano-Frankivsk

The subject of the study is to highlight the issue of the essence of internal (managerial) reporting. To this end, approaches to determine the essence of the internal (management) reporting, the characteristics and requirements for the indicators of such reporting and the specifics of its formation in accordance with the needs of management have been developed. The research uses methods of dialectical analysis and synthesis, as well as methods of logical generalization, comparison and formalization. Requirements for internal (managerial) reporting and qualitative characteristics have been defined, in particular: accuracy, reliability, reliability, conciseness, sufficiency, completeness, usefulness, attitude, expediency. A technological map of the formation of internal (managerial) reporting have been developed and proposed for practical application. This map will facilitate the unified approach to the formation of this reporting. 
Key words: internal (managerial) accounting, requirements for internal (managerial) reporting, qualitative characteristics, principles of formation, technological map.

доктор економічних наук, профресор, Пилипів Н. І., кандидат економічних наук, П'ятничук І. Д., Мотиль В. М. Суть внутрішньогосподарської (управлінської) звітності та вимоги до неї/ Прикарпатський національний університет імені Василя Стефраника, Україна, Івано-Франківськ; Університет Короля Данила, Україна, Івано-Франківськ; Прикарпатський національний університет імені Василя Стефраника, Україна, Івано-Франківськ

Предметом дослідження $\epsilon$ висвітлення питання сутності внутрішньогосподарської (управлінської) звітності. 3 цією метою з'ясовано підходи щодо визначення суті внутрішньогосподарської (управлінської) звітності, особливостей та вимог до показників такої звітності і специфріки ї фрормування відповідно до потреб менеджменту. При проведенні дослідження використано методи діалектичного аналізу та синтезу, а також методи логічного узагальнення, порівняння та фрормалізації. Визначено вимоги до внутрішньогосподарської (управлінської) звітності та якісні характеристики, зокрема це: точність, достовірність, надійність, стислість, достатність, повнота, корисність, зі ставність, доцільність. Розроблена та запропонована до практичного застосування технологічна карта фрормування внутрішньогосподарської (управлінської) звітності, яка сприятиме організації уніфрікованого підходу до фрормування такої звітності.

Ключові слова: внутрішньогосподарська (управлінська) звітність, вимоги до внутрішньогосподарської (управлінської) звітності, якісні характеристики, принципи фрормування, технологічна карта. 
Вступ. Із розвитком ринкових умов стало необхідним ведення управлінського обліку, який, відповідно, супроводжується складанням управлінської звітності. Однак, на сьогодні, немає однозначно визначеної форми такої звітності. Крім того, науковці не дійшли однозначного трактування поняття «управлінська звітність». Також дискусійним $€$ питання щодо переліку, змістового навантаження та оптимального поєднання якісних характеристик, вимог та принципів фрормування звітних показників. Основною проблемою $є$ те, що більшість авторів ототожнюють ці поняття, що підтверджує відсутність однозначності в розумінні категоріального апарату управлінського обліку та звітності.

Проблеми розуміння суті управлінської звітності підприємства досліджуються у працях вітчизняних та зарубіжних науковців, серед яких на особливу увагу заслуговують публікації Юдіна Л. В., Слободяк І. А., Соколов А. Ю., Гусєва О. Е., Друрі К., Попов Н. В., Корягін М. В., Куцик П. О. та ін. У той же час, у працях вчених відсутній єдиний підхід стосовно застосування термінологічного апарату. Теоретичним та методологічним питанням значення та розкриття основних вимог до такої звітності присвячені праці провідних вітчизняних та зарубіжних науковців, зокрема: Палій В. Ф., Адамов М. А., Кольцова Т. А., Коренева А. Н., Ковальов В. В., Михалків А. А., Югансона І. А., Нідлз Б., Андерсен Х., Колдуел Д., Ентоні Р., Ріс Дж.

Метою статті $\epsilon$ вивчення підходів щодо визначення суті внутрішньогосподарської (управлінської) звітності, встановлення іï особливостей та вимог до показників такої звітності і специфіки ії формування відповідно до потреб менеджменту.

Виклад основного матеріалу статті. Невід'ємною складовою управлінського обліку є звітність. Відомо, що чинним законодавством регламентовано лише поняття «внутрішньогосподарський 
(управлінський) облік», а особливості його ведення та документального оформлення належить до компетенції адміністрації суб'єкта господарювання, і $€$ специфічними для різних видів економічної діяльності підприємств. Тому, відповідно до Закону України «Про бухгалтерський облік та фінансову звітність», поняття управлінського обліку є однозначним і звучить так: це система збору, обробки та підготовки інформації про діяльність підприємства для внутрішніх користувачів у процесі управління підприємством [1].

Щодо трактування поняття «управлінська звітність» існує багатозначність. По-перше, щодо трактування самого терміну, подруге, щодо визначення його суті. Так, вченими використовуються наступні трактування для тієї частини бухгалтерської звітності, яка фрормується для надання внутрішнім користувачам для прийняття управлінських рішень: «внутрішня звітність», «внутрішньосистемна звітність», «внутрішньогосподарська звітність», «внутрішня управлінська звітність», «управлінська звітність», «оперативна звітність». На думку, Корягіна М. В. і Куцика П. О., всі перелічені трактування $€$ досить схожими, однак відображають різні характерні особливості того інформаційного продукту, який надається менеджменту підприємства для інтерпретації та прийняття рішень [2, с. 198]. Проте, на наш погляд, буде доцільним не відходити від законодавства і називати таку систематизовану інформацію «внутрішньогосподарською (управлінською) звітністю». Проблема багатозначності визначення суті даного поняття відображена у таблиці 1.

Частина словосполучення «внутрішньо-» вказує не на те, що така звітність користується даними виключно внутрішнього середовища (вона використовує і зовнішні показники), а спрямовує увагу на той 
факт, що інформація такого роду звітності призначена лише для внутрішніх користувачів, іншими словами є конфіденційною.

Таблиця 1

\section{Підходи вітчизняних та зарубіжних науковців щодо означення}

поняття «внутрішньогосподарська (управлінська) звітність» *

\begin{tabular}{|c|c|}
\hline вець & Управлінська звітність - це: \\
\hline 1 & 2 \\
\hline Юдіна Л. В. & $\begin{array}{l}\text { система детальної і конкретної інформації про майно (активи), } \\
\text { капітал, зобов'язання, доходи і витрати підприємства, господарські } \\
\text { процеси і їх результати, про внутрішні і зовнішні фактори, які } \\
\text { вплинули на одержані результати, якає необхідною управлінському } \\
\text { персоналу для прогнозування, планування, організації, контролю і } \\
\text { регулювання діяльності господарюючого суб'єкта [3, с. 2] }\end{array}$ \\
\hline $\begin{array}{c}\text { Слободяк I. } \\
\text { А. }\end{array}$ & $\begin{array}{l}\text { сукупність показників зовнішнього і внутрішнього середовища. } \\
\text { Оскільки показники, що характеризують зовнішнє середовище, } \\
\text { здійснюють у поєднанні з показниками внутрішнього середовища } \\
\text { дуже сильний вплив на прийняття управлінських рішень [4, с. 29] }\end{array}$ \\
\hline $\begin{array}{c}\text { Соколов А. } \\
\text { Ю. }\end{array}$ & $\begin{array}{l}\text { сукупність способів отримання кінцевих даних (відомостей) для } \\
\text { цілей управління компанією. Іншими словами, управлінська } \\
\text { звітність вторинна, вона залежить від організації бухгалтерського } \\
\text { аналітичного обліку, від рівня деталізації активів, зобов'язань, } \\
\text { власного капіталу, доходів і витрат при складанні бюджетів і } \\
\text { обмежена можливостями автоматизованої системи. Разом з тим, } \\
\text { вона багатоваріантна і більш піддається змінам, ніж, наприклад, } \\
\text { методи обліку витрат і калькулювання собівартості продукції [5, с. } \\
\text { 17] }\end{array}$ \\
\hline & $\begin{array}{l}\text { а показників, що характеризує умови і результати діяльності } \\
\text { ємства в цілому чи його окремих частин за звітний період [6, }\end{array}$ \\
\hline Друрі К. & $\begin{array}{l}\text { комплекс взаємопов'язаних даних і розрахункових показників, які } \\
\text { відображають фрункціонування (діяльність) підприємства як суб'єкта } \\
\text { господарювання, згрупованих в цілому по підприємству і його } \\
\text { структурних підрозділах [7, с. 27] }\end{array}$ \\
\hline Попов Н. В. & 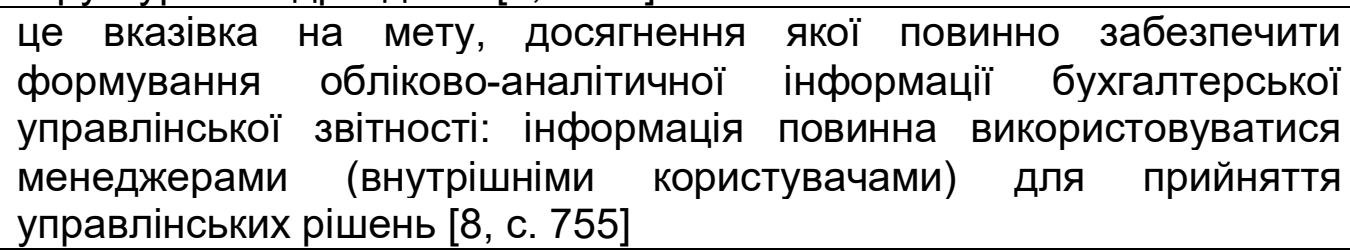 \\
\hline $\begin{array}{r}\text { Корягін I } \\
\text { Куцик Г }\end{array}$ & $\begin{array}{l}\text { це основний засіб інформаційної підтримки } \text { прийняття } \\
\text { менеджментом підприємства управлінських рішень, тобто набір } \\
\text { відповідних облікових показників [2, с. 205] }\end{array}$ \\
\hline
\end{tabular}

* Складено автором на основі джерел [2-8] 
Проведений аналіз наукових праць дозволив виділити значну кількість підходів до виділення вимог, які доцільно буде умовно поділити на такі підпункти: вимоги до вмісту та формування даних, а також вимоги до подання внутрішньогосподарської (управлінської) звітності. Також, варто звернути увагу на те, що управлінський облік $є$ одним із видів бухгалтерського обліку, тому йому притаманні всі якісні характеристики, принципи та вимоги, які передбачені чинним законодавством, а саме: Національне положення (стандарт) бухгалтерського обліку 1 «Загальні вимоги до фрінансової звітності» [9] та Закон України «Про бухгалтерський облік та фрінансову звітність» [1].

Перелік вимог до інформації, яка відображається у внутрішньогосподарській (управлінській) звітності $є$ надто великим, але базовими є такі: точність, достовірність, надійність (користувач повинен бути впевнений, що інформація не містить помилок або пропусків); стислість - інформація повинна бути чіткою, не містити нічого зайвого); достатність, повнота (інформацію доцільно представляти в обсязі, якого достатньо для ухвалення управлінських рішень на відповідному рівні); корисність (інформація повинна давати можливість об'єктивно оцінювати ситуацію); зі ставність (інформація повинна забезпечувати можливість порівнювання показників); доцільність (інформація повинна відповідати тій меті, для якої вона підготовлена) [10, с. 63].

Щодо вимог подання та розповсюдження внутрішньогосподарської (управлінської) звітності, то вони є більш конкретизовані і компактні. Загалом, менеджмент суб'єкта господарювання повинен:

- уникати перевантаження в кількості звітів. Менеджери повинні одержувати тільки ті звіти, які містять інформацію, необхідну їм для виконання своєї роботи. На більш високі рівні управлінської ієрархії повинні надходити тільки зведені звіти; 
- стандартизувати систему поширення звітів. Кожний менеджер повинен бути поінформований, які звіти він буде одержувати; знати, коли вони будуть відправлені, які додаткові звіти він може одержати за запитом;

- установити канали й терміни поширення звітів і їх дотримуватися;

- планувати поширення звітів таким чином, щоб менеджери кожного рівня управління одержували звіти не пізніше від строку їхнього одержання на наступному, більш високому, рівні;

- необхідно знати, які звіти потрібно видалити, а які додати, або модифікувати відповідно до вимог менеджерів.

Слід відмітити, що з метою забезпечення виконання вимог, які ставляться до внутрішньогосподарської (управлінської) звітності необхідним є дотримання принципів ії формування, що сприятиме формуванню повного та якісного інфрормаційного забезпечення процесу прийняття управлінських рішень.

Вивчення спеціальної літератури дало змогу встановити, що основними принципами формування внутрішньогосподарської (управлінської) звітності є: релевантності, оперативності, адресності, достатності, аналітичності, зрозумілості, достовірності, співставності, повного відображення, періодичності, варіативності, конкретності [2, с. 208; 7, c. 29].

У результаті проведеного дослідження щодо вимог до внутрішньогосподарської (управлінської) звітності, виконання яких забезпечується дотриманням принципів її формування, запропонована до практичного застосування технологічна карта, яка сприятиме організації уніфікованого підходу до фрормування управлінської звітності (рис. 1). 


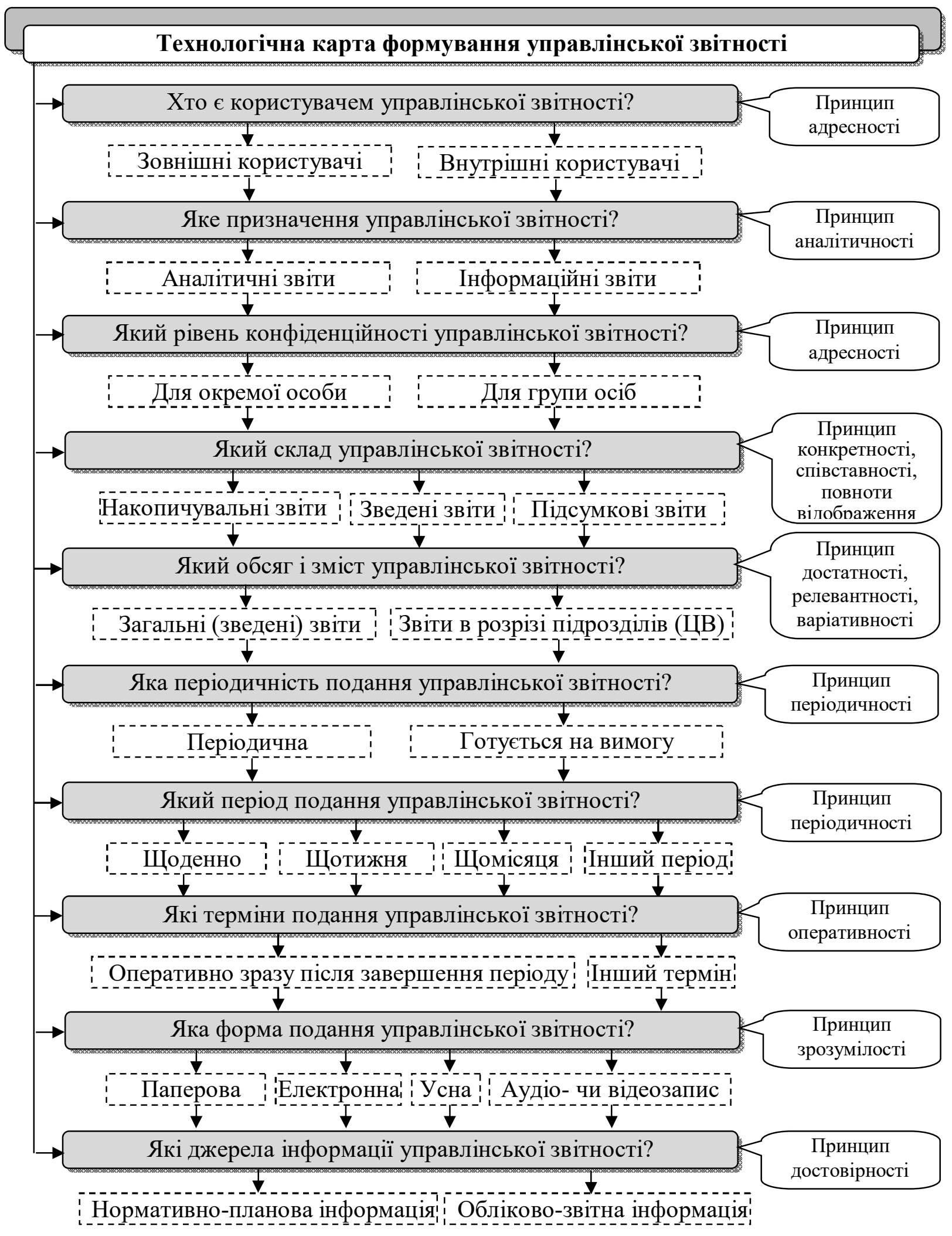

Рис. 1. Технологічна карта формування

внутрішньогосподарської (управлінської) звітності

\section{* Складено автором}

Висновок. Враховуючи неможливість всебічної регламентації методології процесу фрормування внутрішньогосподарської 
(управлінської) звітності, сьогодні вирішення цього питання залишається на рівні пропозицій, які наводяться дослідниками у наукових працях. У ході нашого дослідження було виділено і обґрунтовано найдоцільніше формування терміну внутрішньогосподарської (управлінської) звітності, виділено особливості цього поняття, а також запропоновано базові вимоги до даних звітності та принципи фрормування такої звітності.

\section{תimepamypa:}

1. Закон України «Про бухгалтерський облік та фінансову звітність в Україні» від 16 липня 1999 р. № 996-XIV [Електронний ресурс]. Режим доступу:

http://zakon.rada.gov.ua/cgibin/laws/main.cgi?nreg=996-14.

2. Корягін М. В. Проблеми та перспективи розвитку бухгалтерської звітності [Текст]: монографія / М. В. Корягін, П. О. Куцик. - Київ : Iнтерсервіс, 2016. - 276 с.

3. Юдина Л. Н. Управленческая отчетность организации / Л. Н. Юдина // Все для бухгалтера. - 2007. - № 15(207). - C. 1-14.

4. Слободняк И. А. $K$ вопросу об определении понятия «бухгалтерская управленческая отчетность» / И. А. Слободняк // Вестник ИГЭА. - 2011. - № 4(78). - С. 25-30.

5. Соколов А. Ю. Управленческая отчетность промышленных предприятий / А. Ю. Соколов // Все для бухгалтера. - 2006. - № 19. C. 13-17.

6. Гусева Е. Э. Управленческая отчетность и ее использование для принятия управленческих решений / Е. Э. Гусева // Современный бухучет. - 2005. - № 1. - С. 20-26.

7. Друри К. Управленческий учет для бизнес-решений / К. Друри; [пер. с англ.]. - М.: ЮНИТИ-ДАНА, 2003. - 655 с. 
8. Попов А. Н. Управленческая отчетность: критический аналіз существующих подходов и определений / A. Н. Попов // Фундаментальные исследования. - 2012. - № 6. - С. 753-757.

9. Національне положення (стандарт) бухгалтерського обліку № 1 «Загальні вимоги до фрінансової звітності» [Електронний ресурс]: сайт Верховної ради України. - Режим доступу: http://zakon3.rada.gov.ua/laws/show/z0336-13.

10. Палий В. Ф. Управленческая отчетность: внутрифирменная отчетность / В. Ф. Палий // Бухгалтерский учет. - 2003. - № 13. - С. 62-64.

\section{References:}

1. Zakon Ukrajiny "Pro bukhghaltersjkyj oblik ta finansovu zvitnistj $v$ Ukrajini» vid 16 lypnja 1999 r. № 996-XIV [Elektronnyj resurs]. - Rezhym dostupu: http://zakon.rada.gov.ua/cgibin/laws/main.cgi?nreg=996-14.

2. Korjaghin M. V. Problemy ta perspektyvy rozvytku bukhghaltersjkoji zvitnosti [Tekst]: monoghrafija / M. V. Korjaghin, P. O. Kucyk. - Kyjiv: Interservis, 2016. - $276 \mathrm{~s}$.

3. Yudina L. N. Upravlencheskaya otchetnost organizatsii / L. N. Yudina // Vse dlya bukhgaltera. - 2007. - № 15(207). - S. 1-14.

4. Slobodnyak I. A. K voprosu ob opredelenii ponyatiya «bukhgalterskaya upravlencheskaya otchetnost» / I. A. Slobodnyak // Vestnik IGEA. - 2011. № 4(78). - S. 25-30.

5. Sokolov A. Yu. Upravlencheskaya otchetnost promyshlennykh predpriyatiy / A. Yu. Sokolov // Vse dlya bukhgaltera. - 2006. - № 19. - S. 13-17.

6. Guseva Ye. E. Upravlencheskaya otchetnost $i$ ee ispolzovanie dlya prinyatiya upravlencheskikh resheniy / Ye. E. Guseva // Sovremennyy bukhuchet. - 2005. - № 1. - S. 20-26. 
7. Druri K. Upravlencheskiy uchet dlya biznes-resheniy / K. Druri; [per. s angl.]. - M.: YuNITI-DANA, 2003. - 655 s.

8. Popov A. N. Upravlencheskaya otchetnost: kriticheskiy analiz sushchestvuyushchikh podkhodov i opredeleniy / A. N. Popov // Fundamentalnye issledovaniya. - 2012. - № 6. - S. 753-757.

9. Nacionaljne polozhennja (standart) bukhghaltersjkogho obliku № 1 «Zaghaljni vymoghy do finansovoji zvitnosti» [Elektronnyj resurs]: sajt Verkhovnoji rady Ukrajiny. - Rezhym dostupu: http://zakon3.rada.gov.ua/laws/show/z0336-13.

10. Paliy V. F. Upravlencheskaya otchetnost: vnutrifirmennaya otchetnost/ V. F. Paliy // Bukhgalterskiy uchet. - 2003. - № 13. - S. 62-64. 